\title{
FEDERAL INTERVENTION UNDER THE FOURTEENTH AMENDMENT
}

By Charles Wallace Collins, M.A., Sometime Fellow in the University of Chicago. Member of the Alabama Bar.

It is not the purpose of this article to enter into a discussion of the philosophy of the relation of the States to the Federal government, nor to give an exhaustive treatment of the cases here cited. It is proposed to show in outline the development and trend of the operation of the Fourteenth Amendment in its direct and positive restraint upon the several States within the past forty-three years. The attempt is made to set forth the different spheres of State activity affected and the various classes of laws which have been annulled in whole or in part.

From the time of the adoption of the Fourteenth Amendment in I868 to the close of its last term, the Supreme Court of the United States has handed down six hundred and four opinions under that article of the Constitution. Of these applications for Federal intervention by way of restraining or annulling State action, only fifty-five were decided adversely to the states-that " is to say about nine per cent.

The accompanying chart reveals something of the history and the trend of these instances of intervention. Prior to 1885 there were four such cases, each of which involved the negro race question. These grew out of the problems of the Reconstruction. Since 1886 there have been only two cases of intervention on matters relating to the negro race, while every other instance except twelve has been in behalf of a private corporation seeking relief from State activity, to wit: thirty-nine cases.

For this entire period of forty-three years Federal intervention under the amendment has affected four State constitutions, thirtytwo statutes and nine city ordinances, and State procedureadministrative, executive or judicial-has been restrained eleven times. 'Thirty-six of these cases reached the Supreme Court of the United States by writ of error to the State court, sixteen by appeal from injunctions in the inferior Federal courts and three by other appeals from the Federal courts. Within the past five years nearly one-half of the cases of Federal intervention have 
been by the way of Federal injunctions. Out of the total number of cases of intervention twenty-one involved the interpretation of some other clause of the Constitution, eight of these being the commerce clause. In eight cases the merits were left undecided, and in thirty-eight-a little over one-half-there were dissenting opinions.

It is apparent that all of these cases are not of equal importance. Some of them involve the technicalities of legal procedure. Others deal with questions no longer alive in the body politic. Others annul statutes and declare principles of prime importance. While the total number of interventions is not significant as compared with the total number of opinions handed down, yet their effect has been far-reaching on the relations of the States to the Federal government. The restraining of the activity of one State lays down in some measure the metes and bounds for the other States. Social and economic movements involving several States have been thus checked in their incipiency.

Let us now pass to a more definite consideration of these instances of intervention with a view of seeing more clearly this phase of the practical operation of the amendment. We shall consider first certain miscellaneous cases of more or less importance, but which represent isolated instances of Federal intervention. We shall then proceed to study the more important groups.

I. Presumption of death. Under probate procedure in the State of Washington, a certain man having been absent from the State for seven years, and whose whereabouts were unknown, was declared to be dead and letters of administration were issued. He subsequently reappeared and brought suit in ejectment to recover the land. An adverse decision having been rendered by the State courts, upon writ of error, the Supreme Court of the United States declared such action of the State violative of the due process clause of the Fourteenth Amendment. ${ }^{1}$

2. Service of process. A Texas court served process on a defendant in Virginia, summoning him to appear in the Texas court within five days. This action was upheld by the Supreme Court of Texas. Upon writ of error the Supreme Court of the United States declared the notice insufficient as depriving the defendant of due process of law in contravention of the Fourteenth Amendment. ${ }^{2}$ Fuller, C. J., and Brewer, J., dissented.

1 Scott v. McNeal, 154 U. S., 34. Oct. Term, 1893.

2 Roller v. Holly, 176 U. S., 398. Oct. Term, 1899. 
3. Eminent domain. (a) Procedure in Kentucky to condemn certain lands for a right of way. ${ }^{3}$ On the ground of the nonresidence of the defendant, and under the due process of law clause of the Fourteenth Amendment, the case was removed to the Federal court. A Federal injunction was thenceforth issued to restrain further proceedings in the State court. On appeal the Supreme Court of the United States upheld the injunction. The merits of the case were not decided. ${ }^{4}$ Fuller, C. J., Holmes, Brewer and Peckham, JJ., dissented.

(b) Condemnation of certain lands under a New York statute for the purpose of an elevated railroad." Injunctions were sought in the State courts by property owners to prevent alleged damages to easements. The contract clause of the Constitution was the predominant issue although violation of the due process clause of the Fourteenth Amendment was set up. Relief having been denied by the State courts, upon the proper proceedings had, the Supreme Court of the United States upheld the contention of the parties aggrieved. ${ }^{6}$ Holmes, J., Fuller, C. J., White and Peckham, JJ., dissented. Brown, J., concurred in the result.

4. Public health. A law was passed in the State of New York limiting the working period of employees in bakeries to a maximum of sixty hours per week. ${ }^{7}$ Suit was brought to test the constitutionality of this law under the Fourteenth Amendment. The State courts of New York held it to be a valid exercise of the police power. Upon writ of error the Supreme Court of the United States declared the same void on the ground that it operated to violate the liberty of contract under the due process of law clause of the amendment. ${ }^{8}$ Harlan, White and Day, JJ., dissented. Holmes, $\mathrm{J}$., dissented in a separate opinion.

5. Conservation of natural resources. A statute of Oklahoma prohibited the transportation of natural gas from the State and otherwise regulated the transportation of natural gas within the

${ }^{3}$ Kentucky Stat., Sec. 835-839.

4 Madisonville Traction Co. v. Mining Co., 196 U. S., 239. Oct. Term, 1904.

5 New York Laws, 1892, Chap. 339.

${ }^{6}$ Muhlker v. N. Y. \& Harlem R. R. Co., 197 U. S., 544. Oct. Term, 1904.

Birrell v. N. Y. \& Harlem R. R. Co., 198 U. S., 390. Oct. Term, 1904.

TNew York Laws, 1897, Ch. 415, Art. 8, Sec. 110.

s Lochner v. New York, 198 U. S., 45. Oct. Term, 1904. 
State. ${ }^{\circ}$ A foreign gas company secured a Federal injunction. restraining the execution of the statute on the ground of violation of the interstate commerce clause of the Constitution and also of deprivation of property without due process of law in contravention of the Fourteenth Amendment. The commerce clause was the predominant issue. On appeal by the State the injunction was sustained. ${ }^{10}$ Holmes, Lurton and Hughes, JJ., dissented.

6. Anti-trust legislation. A statute of Illinois for the prevention of monopolies, exempted agricultural products and live stock in the hands of the producer from the operation of the law. ${ }^{11}$ On appeal from proceedings in a Federal court, the Supreme Court of the United States declared the act void on the ground that the exemption above mentioned denied the equal protection of the laws in contravention of the Fourteenth Amendment. ${ }^{12}$ McKenna, J., dissented.

7. City problems. (I) Regulation of the price of gas. The city of Peoria, Illinois, passed an ordinance fixing the maximum price of gas at seventy-five cents per one thousand cubic feet of eighteen candle power. ${ }^{13}$ The gas company petitioned for a Federal injunction to restrain the enforcement of the ordinance on the grounds that the rate violated the contract clause of the Constitution and was confiscatory by virtue of the due process clause of the Fourteenth Amendment. Upon a denial of the petition by the lower court an appeal was taken to the Supreme Court of the United States whereupon the lower court was reversed and ordered to grant a temporary injunction pending the taking of testimony. ${ }^{14}$ The merits of the case were not decided.

(2) Prescribing lawful territory for gas works. An ordinance of Los Angeles limited the erection of gas works to certain sections of the city. A later amendment made some changes in the territory prescribed by the original ordinance, thereby excluding from the lawful territory a certain gas plant. ${ }^{15}$ Upon proceed-

'Oklahoma Laws, 1907, Ch. 67.

${ }^{10}$ Oklahoma v. Kansas Natural Gas Ço., 221 U. S., 229. Oct. Term, 1910.

${ }^{11}$ Laws of Illinois, 1893, p. 182.

${ }^{12}$ Connolly v. Union Sewer Pipe Co., 184 U. S., 540. Oct. Term, 1901.

${ }^{13}$ Peoria Ordinance, Sept. 4, 1900.

14 Gas Co. v. Peoria, 200 U. S., 49. Oct. Term, 1905.

${ }^{15}$ Los Angeles Ordinance, Aug. 26, 1901 ; amended Nov. 25, 1901. 
ings in the State courts, the owner of the gas works set up the claim that the amendment of the original ordinance deprived him of his property without due process of law in contravention of the Fourteenth Amendment. The State courts upheld the validity of the ordinance. Upon writ of error the Supreme Court of the United States held that the amendment to the ordinance was "an arbitrary and discriminatory exercise of the police power" and therefore void by virtue of the Fourteenth Amendment. ${ }^{16}$

(3) Public convenience and safety. The city of San Francisco passed an ordinance regulating certain phases of the laundry business. ${ }^{17}$ Certain Chinese set up the claim that the manner in which it was being enforced deprived them of the equal protection of the laws in contravention of the Fourteenth Amendment. Upon certain proceedings had in the State courts and in the lower Federal court, the matter was decided in favor of the city. Upon appellate proceedings in the Supreme Court of the United States both the State and the Federal courts were reversed and the contention of the Chinese upheld. ${ }^{18}$

(4) Street improvement. The ordinances, one involving an assessment for street paving in Des Moines against the property of a non-resident, and the other a proceeding to condemn certain property for opening a street in the village of Norwood, Ohio, were held by the Supreme Court of the United States to be in violation of the due process clause of the Fourteenth Amendment. The Towa case was tried in the State courts. ${ }^{19}$ In the Ohio case a Federal injunction was allowed restraining the enforcement of the ordinance. ${ }^{20}$ Brewer, Gray and Shiras, JJ., dissented.

(5) Regulation of street railways. An ordinance of the city of Cleveland, Ohio, fixed the title to certain rails, poles, and other apparatus owned by the street railway company, in the city, to take effect at the expiration of the franchise. ${ }^{21}$ The company procured a Federal injunction restraining the enforcement of the ordinance on the ground of the violation of the contract clause of the Constitution and also, of the due process of law clause of the Fourteenth Amendment. Upon appellate proceedings this con-

${ }^{10}$ Dobbins v. Los Angeles, 195 U. S., 223. Oct. Term, 1904.

15an Francisco Ordinance. May 26, 1880 and June 28, 1880.

${ }^{18}$ Yick $W o$ v. Hopkins, 118 U. S., 356. Oct. Term, 1885.

${ }^{19}$ Dewey v. Des Moines, 173 U. S.,- 193. Oct. Term, 1898.

${ }^{20}$ Norwood v. Baker, 172 U. S., 269. Oct. Term, 1898.

${ }_{21}$ Cleveland Ordinance. Jan. 11, 1904. 
tention was upheld by the Supreme Court of the United States.22

(6) Regulation of telephone rates. The enforcement of an ordinance of Memphis, Tennessee, regulating telephone rates, ${ }^{23}$ was enjoined by the Federal court upon the petition of the telephone company. A permanent injunction was allowed on the ground that the rates were confiscatory in violation of the due process clause of the Fourteenth Amendment. On appeal by the city the Supreme Court of the United States dismissed the appellate proceedings on the ground that the Federal question under the Amendment did not properly appear from the pleadings. ${ }^{24}$ White, C. J., McKenna and Hughes, JJ., dissented.

(7) Taxation. (a) An ordinance of the city of New Orleans imposing a license tax of $\$ 6,250$ on the American Sugar Refining Company. ${ }^{25}$ Proceedings in the State court were removed to the Federal court, on the ground of the non-residence of the company. At the trial the company set us as its defense the violation of the equal protection clause of the Fourteenth Amendment. Verdict having been rendered in favor of the city, the case was taken to the Circuit Court of Appeals on writ of error, where it was dismissed for want of jurisdiction. On further appellate proceedings in the Supreme Court the Circuit Court of Appeals was reversed, the Court holding that it had jurisdiction of the constitutional question involved having already jurisdiction by virtue of the non-residence of the company. ${ }^{26}$ The merits were not decided.

(b) An ordinance of the village of New Hope, Pennsylvania, fixing a license tax of one dollar for each pole and two and onehalf dollars for each mile of wire of the telegraph company. The State courts upheld the ordinance. The Supreme Court of the United States, upon writ of error, declared the same void both as a violation of the commerce clause of the Constitution and of the due process clause of the Fourteenth Amendment, the rate being considered unreasonably high. ${ }^{27}$ Harlan and Brewer, JJ., dissented. 1906.

${ }^{22}$ Cleveland Elec. Ry. Co. v. Cleveland, 204 U. S., 116. Oct. Term,

${ }^{23}$ Memphis Ordinance, Sept. 24, 1907.

${ }^{24}$ Memphis v. Cumberland Tel. Co., 218 U. S., 624. Oct. Term, 1910.

${ }^{25}$ New Orleans Ordinance, 1898, under La. Act No. 171 of 1898. 1900.

${ }^{26}$ Am. Sugar Refining Co. v. New Orleans, 181 U. S., 277. Oct. Term,

2т Postal-Tel: Cable Co. v. New Hape, 192 U. S., 55. Oct. Term, 1903. 
(c) Procedure by the city council of Denver, Colorado, sitting. as a board of equalization under the city charter, ${ }^{28}$ fixing tax assessments. The defendant in this case claimed that the assessment was void by virtue of the due process clause of the Fourteenth Amendment in that he was given no opportunity to be heard. Having been denied relief by the State courts, upon writ of error the Supreme Court of the United States upheld his contention. ${ }^{29}$ Fuller, C. J., and Holmes, J., dissented.

8. The Negro race question. There have been six instances of Federal intervention under the amendment on this point; $;$ four growing out of ante-bellum or reconstruction laws and procedure, and two others-one in 1899 and the other in 1903. Each involve the single question of excluding negroes from the jury service. In none of them were the merits of the alleged discrimination decided by the Supreme Court of the United States. In four of these cases there were dissenting opinions. ${ }^{31}$

9. State taxation. (I) Validity of assessment. (a) Procedure under the laws of Georgia ${ }^{32}$ to collect back taxes from a railroad. The company set up the claim in the State courts that the enforcement of this law deprived it of its property without due process of law as provided by the Fourteenth Amendment. The State courts decided in favor of the validity of the statute. Upon writ of error the Supreme Court of the United States sustained the contention of the railroad company. ${ }^{33}$

(b) Assessment by the Cook County Board of Equalization under the lawes of Illinois. ${ }^{3 t}$ The Chicago Traction Co. and six other corporations, upon petition in the Federal court secured an injunction restraining the collection of taxes under the above

2s Denver Charter, 1893, Art. 7, Sec. 3, 29-31.

${ }^{20}$ Londoner v. Denver, 210 U. S., 373. Oct. Term, 1907.

${ }^{30}$ Strauder v. West Va., 100 U. S., 303. Oct. Term, 1879.

Ex parte Virginia, 100 U. S., 339. Oct. Term, 1879.

Neal v. Delaware, 103 U. S., 370. Oct. Term, 1880.

Busle v. Kentucky, 107 U. S., 110. Oct. Term, 1882.

Carter v. Texas, 177 U. S., 442. 'Oct. Term, 1899.

Rogers v. Alabama, 192 U. S., 226. Oct. Term, 1903.

31 See American Law Review, 1911, pp. 835-41, 850-51; The Fourteenth

Amendment and the Negro Race Question, Collins.

32 Gérgia Political Code, Sec. 804-5, 812-14, 847, 855, 874, 879.

${ }^{33}$ Cent. Ga. Ry. Co. v. Wright, Compr., 207 U. S., 127. Oct. Term, 1907.

34 Const. Ill., 1870, Art. 9,-Sec. 1, and Hurd's Rez. Stat., 1899. 
assessment on the ground that the rates were discriminatory, thereby depriving them of the equal protection of the laws. On appeal by the county, the Supreme Court of the United States sustained the injunction..$^{35}$ Holmes and Moody, JJ., dissented.

(2) Taxation of personal property when the situs is in another State. (a) Pennsylvania. Taxation of coal in West Virginia owned by a Pennsylvania railroad. ${ }^{36}$ Upon proper proceedings the State courts were reversed by the Supreme Court of the United States and the assessment held void as a violation of the due process clause of the Fourteenth Amendment. ${ }^{3 \pi}$ Fuller, C. T., dissented.

(b) Kentucky. Taxation of cars in Indiana owned by a Kentucky railroad under a statute subjecting the personal property of all citizens of Kentucky to taxation in that State regardless of the situs. $^{38}$ The law was declared valid by the State courts. Upon appellate proceedings in the Supreme Court of the United States it was pronounced void in that it took property without due process of law and denied the equal protection of the laws, in violation of the Fourteenth Amendment. ${ }^{39}$ Holmes, J., and Fuller, C. J., dissented.

Kentucky. Taxation of a franchise in Indiana. ${ }^{40}$ The proceedings were similar to the above, the tax being held roid under the due process clause of the amendment. ${ }^{41}$ Fuller, C. J., and Shiras, J., dissented.

Kentucky. Taxation of whiskey stored in Germany by owners in Kentucky who held the warehouse receipts. The tax was declared void under the due process clause of the amendment under procedure similar to the above..$^{42}$

(3) Taxation of personal property when the ouner thereof is a non-resident of the State. (a) Indiana. Taxation of notes owned in New York and payable in Ohio. The amount involved was $\$ 750,000$. The Indiana assessment was $\$ 36,357.7$ I. The 1907.

35 Raymond, Treas. v. Clicago Trac. Co., 207 U. S., 20. Oct. Term,

36 Penn. Law's, 1891, p. 229.

${ }^{37}$ Del., L. \& W. R. R. Co. v. Penn., 198 U. S., 341. Oct. Term, 1904. ${ }^{38}$ Sec. $4020, K y$. Stat.

${ }^{39}$ Union Transit Co. v. Kentucky, 199 U. S., 194. Oct. Term, 1905.

40 Sec. 4077, et seq. Ky. Rev. Stat.

${ }^{11}$ Lonisville, etc., Ferry Co. v. Kentucky, 188 U. S., 385. Oct. Term, 1902.

\$2 Selliger v. Kentucky, 213 U. S., 200. Oct. Term, 1908. 
notes were sent to Indiana presumbaly to escape taxation in Ohio. Proceedings in the State courts resulted in a verdict for the State. Upon writ of error the Supreme Court of the United States declared the tax void in that it was a taking of property without due process of law in violation of the Fourteenth Amendment. ${ }^{43}$ Day and Brewer, JJ., dissented.

(b) Louisiana. Taxation of credit notes and bank deposits held in New Orleans by a corporation of New York. ${ }^{44}$ The amount involved was $\$ 636,900$. An injunction from the Federal court restraining the collection of the tax was sustained on appeal, by the Supreme Court of the United States under the due process clause of the amendment as in the above case. ${ }^{45}$ Brewer, J., dissented.

(4) Franchise taxes on corporations. (a) California. Upon suit by the State the company petitioned for a removal of the cause to the Federal court under Act of Congress, March 3, I875, as a suit arising under the Constitution of the United States, violation of the due process and the equal protection clauses of the Fourteenth Amendment being alleged. Upon a denial of the petition by the State courts and proper proceedings had, the Supreme Court of the United States decided in favor of the petitioner. $^{48}$

(b) Kansas. A statute fixing a charter fee for corporations based on a certain per cent of the entire capital stock, the same to be paid into the school fund of the State.47 In this case the fee was $\$ 20,100$. After proceedings in the State courts in which the law was held valid, the Supreme Court of the United States, upon writ of error, declared the statute void in that (I) it imposed a burden on interstate commerce and (2) it violated the due process and the equal protection clauses of the Fourteenth Amendment in taxing property beyond the limits of the State. The defendant was a foreign corporation. The commerce clause was the predominant issue. $^{48}$ Fuller, C. J., Holmes, McKenna, and Peckham, JJ., dissented.

\footnotetext{
43 Buck v. Beach, 206 U. S., 392. Oct. Term, 1906.

4 La. Acts, 1898 , No. 170.

${ }_{45}$ New Orleans v. New York Life Ins. Co., 216 U. S., 517. Oct. Term,

46 Sou. Pac. R. R. Co. v. Cal., 118 U. S., 109. Oct. Term, 1885.

${ }_{4 \pi}$ Kan. Gen. Stat., 1901, p. 280.

${ }_{48}$ West. Union Tel. Co. v. Kan., 216 U. S., 1. Oct. Term, 1909.
} 1909. 
Kansas. The same statute brought in question in quo warranto proceedings against the Pullman Company with the same result as in the above. ${ }^{49}$ Fuller, C. J., Holmes and McKenna, JJ., dissented.

(c) Arkansas. A statute known as the Wingo Act fixed the charter fee of foreign corporations on the same basis as the Kansas law above mentioned. ${ }^{50}$ The charter fee in this case was $\$ 25,050$. A Federal injunction restraining the enforcement of the statute was sustained on appeal by the State, on the authority of the opinions in the Kansas cases. ${ }^{51}$ Fuller, C. J., Holmes and McKenna, JJ., dissented.

(d) Alabama. A statute classifying corporations into foreign and domestic and fixing a charter fee for foreign corporations at a certain per cent of the entire capital stock in use within the borders of the State. ${ }^{62}$. After proceedings in the State courts in which the statute was upheld, the Supreme Court of the United States declared it void in that it deprived the foreign corporations, doing business within the State, of the equal protection of the laws, in contravention; of the Fourteenth Amendment. ${ }^{5 s}$ : Fuller, C. J., Holmes and McKenna, JJ., dissented.

Io. State regulation of public service corporations. (I) Stock yards. Kansas. A statute regulating public stock yards, fixing charges, prescribing duties, and fixing penalties. ${ }^{54}$ A federal injunction restraining the enforcement of the statute 'was sustained by the Supreme Court of the United States, on appeal by the State, on the ground that the statute operated only against the Kansas City Stock Yards Company, thereby violating the equal protection clause of the Fourteenth Amendment.55

(2) Insurance companies. (a) Louisiana. A statute prohibiting the dealing with foreign insurance companies which had not complied with the laws of Louisiana. ${ }^{56}$ The law was declared valid by the State courts. Upon writ of error the Supreme Court

${ }^{49}$ Pullman Co. v. Kan., 216 U. S., 156. Oct. Term, 1909.

50 Ark. Laws, 1907, p. 744.

"L1 Ludwig v. Western U. Tel. Co., 216 U. S., 146. Oct. Term, 1909.

"2 Alabana Code, 1907, Vol. I, p. 986, Sec. 2391-2400.

\$3 Sou. Ry. Co. v. Greene, 216 U. S., 400. Oct. Term, 1909.

L. \& N. R. R. Co. v. Gaston, 216 U. S., 418. Oct. Term, 1909.

Cent. Ga. Ry. Co. v. Gaston, 216 U. S., 418. Oct. Term, 1909.

${ }^{4}$ Kansas Laws, March 3, 1897.

${ }^{5}$ Cotting v. Kan. City Stock Yds. Co., 183 U. S., 79. Oct. Term, 1901.

so Louisiana Laz's, 1894, No. 66. 
of the United States held that it violated the due process clause of the Amendment in that it worked a deprivation of the liberty of contract. ${ }^{57}$

(b) Indiana. Pennsylvania. A judgment was received in a Pennsylvania State court against an insurance company under a statute providing that service of process on the insurance commissioner was sufficient notice.88 "Full faith and credit" was given this judgment in the Indiana courts. Upon writ of error the Supreme Court of the United States declared both judgments void in that the service on the insurance commissioner was insufficient, thereby violating the due process clause of the Fourteenth Amendment. ${ }^{59}$

(3) Recovery of land from railroads. Texas. A suit in 1890 to recover certain sections of land from a railroad company under a legislative grant in I866 on the ground that the grant was made without authority. ${ }^{60}$ Judgment having been rendered for the State in the State courts, upon proceedings in the Supreme Court of the United States the State courts were reversed under the contract clause of the Constitution and under the due process clause of the Fourteenth Amendment. The contract clause was the predominant issue. ${ }^{61}$

(4) Regulation of the collection of claims against railroads. Texas. A statute allowing a ten dollar attorney's fee as a part of the judgment for the plaintiff on certain claims against railroads under certain conditions. ${ }^{62}$ After being upheld in the courts of the State, the statute was declared void by the Supreme Court of the United States in that it violated the due process and the equal protection clauses of the Fourteenth Amendment. ${ }^{63}$ Gray, J.r Fuller, C. J., and White, J., dissented.

(5) Regulation of railroad profits. Indiana. A statute regulating the profits of railroads within the state. ${ }^{64}$ In this case the construction of a charter of 1847 was involved. Upon proceed-

57 Allgeyer v. Lonisiana, 165 U. E., 578. Oct. Term, 1896.

${ }_{58}$ Penn. Laws, June 20, 1883. 1906.

59 Old Wayne Life Ins. Assn. v. McDonongh, 204 U. S., 8. Oct. Term,

${ }^{60}$ Constitution of Texas, 1869, Sec. 6, Art. 10.

${ }^{61}$ Houston \& Tex. Cent. Ry. Co. v. Texas, 170 U.-S., 243. Oct. Term, 1897.

${ }^{62}$ Sayles Supp. Tex. Civil Stat., p. 768, Art. 4266a.

${ }^{63}$ Gulf Colo. \& Santa Fe Ry. v. Ellis, 165 U. S., 150. Oct. Term, 1896.

${ }^{64}$ Indiana Laws, Jan. 27, Feb. 24, and March 4, 1897. 
ings by writ of error the Supreme Court of the United States declared the law violative of the contract clause of the Constitution and of the due process clause of the Fourteenth Amendment. The contract clause was the predominant issue..$^{65}$

(6) Compulsory improvement of the railroad service. (a) Nebraska. An order of the State Board of Transportation compelling a railroad company to allow the erection of certain grain elevators on its right of way. ${ }^{66}$ A mandamus was awarded by the State court to enforce this order. Upon writ of error the Supreme Court of the United States declared the proceedings to be in violation of the due process clause of the Fourteenth Amendment. ${ }^{67}$

(b) Nebraska. A statute compelling railroad companies to construct and maintain certain sidetracks and switches for certain grain elevators adjacent to the right of way. ${ }^{68}$ After procedure in the State courts upholding the statute the Supreme Court of the United States declared it unconstitutional on the grounds menioned in the preceding case. ${ }^{60}$ Harlan and McKenna, JJ., dissented.

(c) Kentucky. A provision of the State Constitution compelling railroad companies, under certain conditions, to deliver cars to other railroads. ${ }^{70}$ After procedure in the State courts upholding the constitutional provision, the Supreme Court of the United States declared it void in that it placed a burden on interstate commerce and violated the due process clause of the Fourteenth Amendment. ${ }^{11}$ McKenna, Harlan and Moody, JJ., dissented.

(7) Regulation of the rates of common carriers. (a) Texas, Fixing the rates by the Railroad Commission. ${ }^{72}$ A Federal injunction was sustained by the Supreme Court of the United States, on appeal by the State, on the ground that the proposed rates worked a deprivation of property without due process of law and denied the equal protection of the laws, in violation of the Four-

o5 T. H. \& Ind. R. R. Co. v. Indiana, 194 U. S., 579. Oct. Term, 1903.

Go Dec. 13, 1889.

${ }^{07}$ Mo. Pac. Ry. v. Neb., 164 U. S., 403 . Oct. Term, 1896.

${ }^{68}$ Nebraska Session Laws, 1905, Ch. 105, Sec. 1, 6.

${ }^{60}$ Mo. Pac. Ry. Co. v. Neb., 217 U. S., 196. Oct. Term, 1909.

${ }^{70}$ Kentucky Constitution, Sec. 213-14.

${ }^{71}$ L. \& N.'R. R. Co. v. Cent. Stock Yds. Co., 212 U. S., 132. Oct. Term, 1908.

- 72 Texas Lazes, April 3, 1891. 
teenth Amendment. The Eleventh Amendment was also involved. ${ }^{73}$

(b) Minnesota. I887. An order of the Railroad and Warehouse Commission fixing rates. ${ }^{74} \mathrm{~A}$ mandamus was awarded by the State courts to compel compliance with the order. Upon writ of error the Supreme Court of the United States annulled the order on the ground that it violated the due process and the equal protection clauses of the Fourteenth Amendment, in that the notice of the hearing was insufficient. ${ }^{75}$ Bradley, Gray and Lamar, JJ., dissented.

(c) Minnesota. 1907. Certain statutes provided for a two-cent passenger rate and the regulation of freight rates. ${ }^{76}$ Penalties were also fixed. A Federal injunction was allowed restraining the attorney general of the State from enforcing the statute on the ground that such enforcement would work a deprivation of property without due process of law contrary to the Fourteenth Amendment. The attorney general refused to obey the injunction and was thereupon confined for contempt. He petitioned for a writ of habeas corpus in the Supreme Court of the United States on the ground that the injunction was in violation of the Eleventh Amendment. His petition was denied. The merits of the rate law were not decided. ${ }^{77}$ Harlan, J., dissented.

(d) Kentucky. A statute reducing tolls. ${ }^{78}$ An injunction was granted by the State courts to prevent a contravention of the statute. Upon writ of error the Supreme Court of the United States dissolved the injunction on the ground that the statute was a prima facie violation of the due process and the equal protection clauses of the Fourteenth Amendment. The merits were not decided..$^{79}$

(e) Kentucky. An order of the Railroad Commission fixing general tariff rates. ${ }^{80}$ A Federal injunction preventing the enforcement of the order was sustained by the Supreme Court of 1893.

${ }^{73}$ Reagan v. Farmers Loan \& Trust Co., 154 U. S., 362. Oct. Term,

Reagan v. Mercantile Trust Co., 154 U. S., 413. Oct. Term, 1893.

74 Minn. Gen. Laze's, Ch. 10, 1887.

${ }^{75}$ Chicago, Mil. \& St. P. Ry. v. Minn., 134 U. S., 418. Oct. Term, 1889.

76 Minn. Rate Laws, 1905, 1906, 1907.

77 Ex parte Young, 209 U. S., 125. Oct. Term, 1907.

${ }^{78}$ Kentucky Laws, 1890.

${ }^{79}$ Covington Turnpike Co. z'. Sanford, 164 U. S., 578. Oct. Term, $1890^{\circ}$.

so Kentucky Lazws, March 10, 1900. 
the United States, on appeal by the State, under the due process and equal protection clauses of the Fourteenth Amendment on the ground that the commission exceeded its authority. The commerce clause was also involved. ${ }^{81}$

(f) Nebraska. An order of the Board of Transportation fixing freight rates. ${ }^{82}$ A Federal injunction restraining the enforcement of the order was sustained by the Supreme Court of the United States, on appeal by the State, under the due process and equal protection clauses of the Fourteenth Amendment on the ground that the rates were too low..$^{83}$

(g) Nebraska. This was a further attempt to enforce the above mentioned rate law. A Federal injunction was sustained as in the above..$^{84}$

(h) South Dakota. Order of the Railroad Commission regulating rates. ${ }^{85} \mathrm{~A}$ petition for an injunction on the basis of a violation of the Fourteenth Amendment, was denied by the Federal court. On appeal the Supreme Court of the United States granted a temporary injunction with instructions to refer the case to a master to ascertain the facts. ${ }^{88}$

(i) Michigan. A statute of Michigan provided, among other things, that $1,000-$ mile railroad tickets should be valid for two years from the date of purchase and redeemable within that time at the rate of three cents per mile. ${ }^{87}$ After procedure in the State courts in which the provision was declared valid, the Supreme Court of the United States, upon writ of error, held it to be void under the due process and the equal protection clauses of the Fourteenth Amendment. ${ }^{88}$ Fuller, C. J., Gray and McKenna, JJ., dissented.

The foregoing bare outline of facts is shown here void of local coloring. The peculiar circumstances which gave rise to the laws in question, the reasons which led the State courts to uphold them, and the public opinion of the States which approved them cannot be shown in this study, nor can they be fully understood by those

s1 Siler v. L. \& N. R. R. Co., 213 U. S., 175. Oct. Term, 1908.

82 Nebraska Rate Law, April 12, 1893.

s3 Smyth v. Ames, 169 U. S., 466. Oct. Term, 1897.

st Prout v. Starr, 188 U. S., 537. Oct. Term, 1902.

s5 South Dakota Lazes, 1897, Ch. 110. 1899.

${ }^{80}$ Chicago, M. \& St. P. Ry. v. Tompkins, 176 U. S., 167. Oct. Term,

si Michigan Laws, 1891. Act No. 90, Sec. 9.

${ }^{88}$ Lake Shore \& Mich. Ry. v. Smith, 173 U. S., 684. Oct. Term, 1898. 
living outside of the State in question, unconnected with the local problem involved. In such a presentation as this we see only one side of the question-the Federal side.

Within the past forty-three years twenty-five States have been directly affected by Federal intervention under the Amendment. ${ }^{\text {so }}$ This involved the annulment in whole or in part of thirty-two statutes, nine city ordinances, and a portion of four State constitutions. As to the total number of the fifty-five instances of intervention, eleven were made under the equal protection clause of the Amendment, six of these involving the right of negroes to sit on juries; fourteen were made under the equal and the due process of law clauses considered together; and the remaining thirty were made under the due process of law clause alone, two as deprivations of liberty without due process of law, and twentyeight as taking property without due process of law.

Although there are before us six hundred and four opinions handed down by the Supreme Court of the United States under the Fourteenth Amendment, in fifty-five of which the Federal government was allowed to intervene in the affairs of the State, it is very difficult to formulate general principles governing this intervention. The terms "due process of law" and "equal protection of the laws," for this purpose, mean nothing in themselves. They gain their meaning only from the conditions and circumstances of each particular case. Matters of time, space and manner govern their interpretation. They cannot be detached from the concrete local environment.

However, we can trace the path in which Federal intervention has heretofore moved and see something of its chronological development. The first instance of intervention was in 1879 , eleven years after the adoption of the Amendment, when a law of the State of West Virginia was declared void because it excluded negroes from the jury service. ${ }^{90}$ In 1885 the enforcement of an ordinance in California was restrained on account of discrimination against the Chinese. ${ }^{91}$ In I889 the State of Minnesota was restrained from enforcing its railroad rate law. ${ }^{92}$ This

89 See Chart II.

${ }^{90}$ Strauder v. West Virginia, 100 U. S., 303.

91 Yick Wo v. Hopkins, 118 U. S., 356.

${ }^{22}$ Chi., Mil. \& St. P. Ry. v. Minn., 134 U. S., 418. 
was followed by similar action as to the Texas rate law of $x 893{ }^{93}$ and the Nebraska rate law in $1897 .^{.4}$

In I896 the State of Nebraska was prohibited from enforcing a law regulating the erection of grain elevators on the right of way of railroads, ${ }^{95}$ and the State of Louisiana from enforcing a law regulating the dealing of its citizens with foreign insurance companies. ${ }^{96}$ In 1898 the enforcement of one city ordinance in Ohio, ${ }^{97}$ and another in Iowa, ${ }^{98}$ was restrained as taking property without due process of law. In Igor a stock yard law of Kansas ${ }^{93}$ and an anti-trust law of Illinois ${ }^{100}$ were annulled. In I904 a law of New York regulating the hours of labor in bakeries was declared void. ${ }^{101}$ In 1907 the States of Georgia and Illinois were restrained from collecting certain taxes from certain corporations. ${ }^{102}$ In Igog the enforcement of the franchise tax laws of Arkansas, ${ }^{103}$ Kansas, ${ }^{104}$ and Alabama, ${ }^{105}$ and ${ }^{\circ}$ law of Nebraska regulating railroad sidetracks and switches, ${ }^{100}$ were restrained.

We thus see that Federal intervention under the amendment has gradually drifted away from race questions and has within recent years entered other fields of State activity. It has become directly related to the most serious problems that engage the nation. This gradual development of intervention under the amendment has not been accomplished without opposition, even in the Supreme Court of the United States itself. In ten of the eighteen cases above cited there were dissenting opinions.

We cannot answer the question as to how far Federal intervention can go under the Fourteenth Amendment. We can see how far it has gone, but a study of all of these cases fails to

${ }^{\circledR 3}$ Reagan v. Farmers Loan \& Trust Co., 154 U. S., 362.

94 Smyth v. Ames, 169 U. S., 466.

va. Mo. Pac. Ry. v. Neb., 164 U. S., 403.

${ }^{96}$ Allgeyer v. Lonisiana, 165 U. S., 578.

${ }^{97}$ Norwood v. Baker, 172 U. S., 269.

9s Dewey v. Des Moines, 173 U. S., 193.

99 Cotting v. Kansas, 183 U .S., 79.

${ }^{100}$ Connolly v. Union Sewer Pipe Co., 184 U. S., 540.

101 Lochner v. New York, 198 U. S., 45.

${ }^{102}$ Central of Ga. Ry. Co. v. Wright, 207 U. S., 127.

Raymond, Treas. Cook Co. v. Chicago Trac. Co., 207 U. S., 20.

${ }^{103}$ Ludwig v. West. U. Tel. Co., 216 U. S., 146.

104 West. U. Tel. Co. v. Kansas, 216 U. S., 1. .

Pullman Co. v. Kansas, 216 U. S., 156.

105 Sou. Ry Co. v. Greene, 216 U. S., 400.

${ }^{106}$ Mo. Pac. Ry. Co. v. Nebraska, 217 U. S., 196. 
enable one to set limitations for the amendment in the future, under the present Federal procedure. For practical purposes. this principle of intervention may be stated in the following words: No State can make or enforce any law which shall, upon proper proceedings, be deemed unreasonable by a majority of the Supreme Court of the United States. This involves the interpretation in each case of the terms "due process of law" and "equal protection of the laws." The rule of reason alone governs. What are fair profits, what are excessive taxes, what are proper health laws, what is confiscation and what discrimination - these are questions which cannot be answered in the abstract: nor can they be adequately defined by precedents. If it becomes. incumbent on the Supreme Court of the United States to pass judgment on them, it must consider the reasonableness of eack concrete case.

Charles Wallace Collins.

Washington, D. C., March, 1912. 
CHART No. I.

CHRONOLOGICAL TABLE SHOWING THE NUMBER AND CHARACTER OF FEDERAL INTERVENTIONS UNDER THE FOURTEENTH AMENDMENT, I868-I9II.

\begin{tabular}{|c|c|c|c|c|c|c|c|c|c|c|c|c|c|c|c|c|c|c|}
\hline 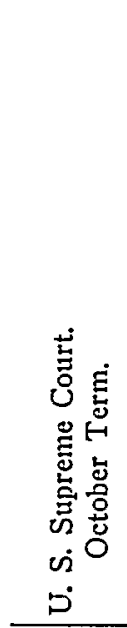 & 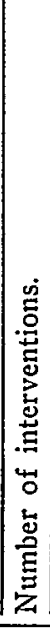 & 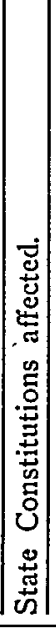 & 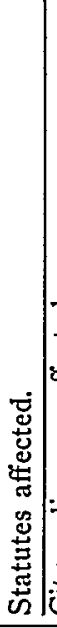 & 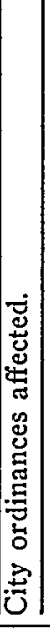 & 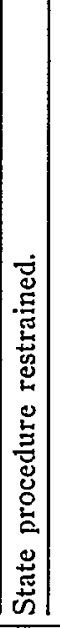 & 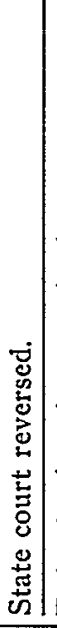 & 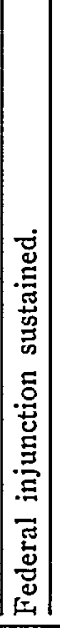 & 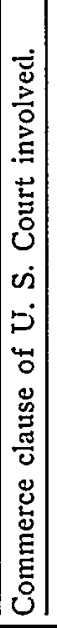 & 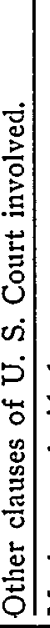 & 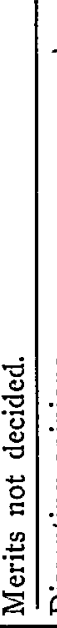 & 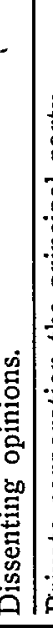 & 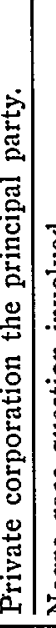 & 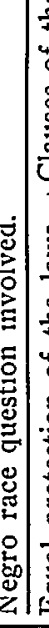 & 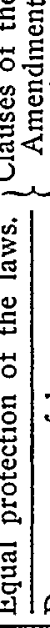 & 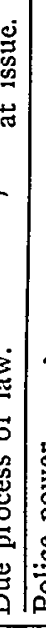 & & & . \\
\hline 879. & 2 & & I) & & I) & II & & & & I & $2 \mid$ & & 21 & & 21 & $2 \mid$ & & \\
\hline (1) & I & $\mathrm{I}$ & & & & I & & & & & I & & $\mathbf{I}$ & & I & I & & \\
\hline 2. & I & & $\mathrm{r}$ & & & $\mathrm{I}$ & & & & & $\mathrm{I}$ & & I & & I & & & \\
\hline 85 & 2 & & & & 2 & 2 & & & & $\mathrm{I}$ & & $\mathrm{I}$ & & $\mathbf{I}$ & 2 & & $\mathbf{I}$ & \\
\hline I889. & $\mathrm{I}$ & & $\mathrm{I}$ & & & $I$ & & & I & & I & $\mathrm{I}$ & & I & $\mathrm{I}$ & 1 & & \\
\hline 93. & 2 & & $\mathrm{I}$ & & $\mathrm{I}$ & $\mathrm{I}$ & $\mathrm{I}$ & & $\mathrm{I}$ & & & $\mathrm{I}$ & & 2 & & 2 & & \\
\hline & 4 & & 4 & & & 4 & & & $\mathrm{I}$ & & & 4 & & & 2 & +1 & & \\
\hline 77 & 2 & $\mathrm{I}$ & 2 & & & $\mathrm{I}$ & $I$ & & 2 & & & 2 & & 2 & $\mathrm{I}$ & 2 & & \\
\hline 308 & 3 & & $\mathrm{I}$ & 2 & & 2 & I & & $\mathrm{I}$ & & 2 & $\mathrm{x}$ & & $3 \mid$ & $\mathrm{I}$ & & I & I \\
\hline 189. & 3 & & $\mathrm{I}$ & & 2 & 2 & I & & & 2 & I & $\mathrm{I}$ & $\mathrm{I}$ & 2 & 2 & & & \\
\hline & I & & $\mathrm{I}$ & $\mathrm{I}$ & & & & & & $\mathrm{I}$ & & $\mathrm{I}$ & & & I & & I & \\
\hline & 2 & & 2 & & & & $\mathrm{I}$ & & & & I & 2 & & & 2 & 2 & & \\
\hline & 2 & & $\mathrm{I}$ & & & $\mathrm{I}$ & I & & I & & $\mathrm{I}$ & 2 & & 2 & I & I) & I & \\
\hline & 3 & & $\mathrm{I}$ & I & $\mathbf{I}$ & 3 & & $\mathrm{I}$ & $\mathrm{I}$ & & I & 2 & $\mathrm{I}$ & I & 2 & & & \\
\hline & 6 & & 4 & I & & 5 & $\mathrm{I}$ & & 2 & $\mathrm{I}$ & & 4 & & 6 & & & I & 2 \\
\hline & 2 & & I) & I & & $\mathrm{I}$ & I) & & I & & & 2 & & & I & & I & \\
\hline & 3 & & $\mathbf{I}$ & I & 2 & 2 & I & & 2 & & & 2 & & 3 & & & & I \\
\hline & 4 & I) & 3 & $I$ & & 2 & $2 \mid$ & $\mathrm{I}$ & & & & l & & & I & & & \\
\hline & 3 & I & & & 2 & 2 & $\mathrm{I}$ & 2 & & & & 4 & & & I & & I & \\
\hline & 4 & & 5 & & & 4 & 2 & 1) & & & 6 & 6 & & 5 & 3 & & 5 & \\
\hline & 21 & & & 11 & & & $2 !$ & & & I| & & $2]$ & & & & & & \\
\hline
\end{tabular}

- Total. $|55| 4|32|$ 9|II|36|I6| 8|I3| 8|3r|39| 6|42|25|35|r6| 4 
CHART No. II.

TERRITORIAL OPERATION OF FEDERAL INTERVENTTION UNDER THE FOURTEENTH AMENDMENT, I868-I9II.

\begin{tabular}{l|llllll} 
Kentnucky & \\
Texas & \\
Nebraska & \\
California & \\
Illinois & \\
Indiana & \\
Kansas \\
Louisiana & \\
New York & \\
Pennsylvania & \\
Alabama & \\
Minnesota & \\
Ohio & \\
Arkansas & \\
Colorado & \\
Delaware & \\
Georgia & \\
Iowa \\
Michigan \\
Oklahoma \\
South Dakota \\
Tennessee \\
Virginia \\
Washington \\
West Virginia
\end{tabular}

